Original Paper http://ajol.info/index.php/ijbcs http://indexmedicus.afro.who.int

\title{
Incidence of latex harvesting technologies on agronomic and physiological parameters and profitability of some rapid metabolic class clones of rubber tree (Hevea brasiliensis) in southwestern Côte d'Ivoire
}

\author{
G.J.O. ATSIN ${ }^{1 *}$, E.F. SOUMAHIN ${ }^{2}$, A. MAHYAO ${ }^{3}$, K.M. OKOMA ${ }^{4}$, T.H. KOUAKOU ${ }^{5}$ \\ and S. OBOUAYEBA ${ }^{1}$
}

${ }^{I}$ National Center for Agronomic Research (CNRA), Research Station of Bimbresso, Laboratory of Agronomy and Plant Physiology, 01 BP 1536 Abidjan 01, Côte d'Ivoire.

${ }^{2}$ University Jean Lorougnon Guédé, UFR (Faculty) of Agroforestry,

Laboratory of Plant Physiology and Pathology BP 150 Daloa, Côte d'Ivoire.

${ }^{3}$ CNRA, Research Station of Gagnoa, BP 602 Gagnoa, Côte d'Ivoire.

${ }^{4}$ CNRA, Central Laboratory of Biotechnology. 01 BP 1740 Abidjan 01, Côte d'Ivoire.

${ }^{5}$ University Nangui Abrogoua, UFR (Faculty) of Natural Sciences, Laboratory of Biology and Improvement of Plant Productions, 02 BP 801 Abidjan 02, Côte d'Ivoire.

*Corresponding author; E-mail: olivieratsin@yahoo.fr

\begin{abstract}
Rubber tree rapid-metabolism clones generally have interesting agronomic and physiological characteristics. However, they are mostly sensitive to tapping panel dryness and breakage due to wind. This could be probably due to overexploitation caused by high tapping frequencies and/or high hormonal stimulation systems. To try solving this problem, a study was carried out over nine years using clones PB 260, PB 280 and PB 330 planted at a density of 510 plants/ha in southwestern Côte d'Ivoire. The experimental design was a randomized complete blocks with different latex harvesting technologies. The estimated parameters were rubber yield, radial vegetative growth, physiological profile and the profitability of applied latex harvesting technologies. Results indicated that non-stimulated combined with high tapping frequency latex harvesting system (d2 0/y) showed a level of rubber yield comparable to that of tapping frequencies $\mathrm{d} 3$ and $\mathrm{d} 4$ in all studied clones irrespective of the level of hormonal stimulation applied. Furthermore, the absence of hormonal stimulation had no negative influence on the vegetative growth and the physiological profile of rubber trees. Every two days (d2) tapping system without stimulation generated a profit margin statistically identical to that of low tapping frequencies (d4, d5 and d6) irrespective of the level of hormonal stimulation. (C) 2017 International Formulae Group. All rights reserved.
\end{abstract}

Keywords: Rapid-metabolism clones, Côte d'Ivoire, tapping frequency, Hevea brasiliensis, rubber yield, physiological profile. 


\section{INTRODUCTION}

Setting up latex harvesting technologies adapted to rubber tree clones has always been a major concern for the rubber industry in Côte d'Ivoire (Obouayeba et Boa 1993; Coulibaly, 2012). Rubber tree clones have been the subject of major works in the field of plant and latex physiology (Jacob et al., 1988; Lacrotte, 1991; Gohet, 1996). These works helped group clones into three metabolic activity classes' slow, moderate and rapid (Serres et al., 1994; Jacob et al., 1995; Gohet et al., 1996). Rapid metabolic activity class includes clones with an easy flow leading to high rubber yield in absence of hormonal stimulation (Chapuset et al., 2000; Atsin et al., 2016). In spite of these interesting agronomic and physiological characteristics, these clones are basically sensitive to tapping panel dryness and breakage due to the wind. Such sensitivity is probably linked to overexploitation caused by high tapping frequencies and/or high hormonal stimulation systems (Chrestin, 1985; Okoma, 2008).

Findings of Lacote et al. (2010) have demonstrated that tapping, by inducing stress, activates the metabolism of latex vessels as well as hormonal stimulation by producing ethylene. Indeed, ethylene, produced and released during stress in the tissues, activates the entire biosynthesis process of the cispolyisoprene molecule or rubber (Lacrotte, 1991; Obouayeba et al., 1996). More importantly, investigations revealed possibilities for adapting latex harvesting technologies to rubber clones to ensure a better balance between agronomic and physiological parameters and sensitivity of rubber trees to tapping panel dryness (Obouayeba et al., 2006, 2008; Soumahin, 2010).

Hence, sustainable harvesting efficiency of the latex in rapid-metabolism clones appears as a main concern for which there is a needs to determining a latex harvesting technology adapted to them. The objective of the study is to assess, firstly, the incidence of latex harvesting technologies on the agronomic and physiological parameters of the rapid metabolic class clones and secondly, on the profitability.

\section{MATERIALS AND METHODS \\ Materials}

Three clones from rapid or active metabolic activity class of rubber tree (Hevea brasiliensis, Muel. Arg., Euphorbiaceae) are used as plant material. These clones are: $\mathrm{PB}$ 260, PB 280 and PB 330.

PB 260 (Prang Besar 260) is a clone obtained by crossing PB 5/51 x PB 49. It originates from Malaysia. According to vegetative growth scale in rubber tree, that of clone PB 260 range from medium to good before tapping. And after tapping its vegetative growth remains medium. it's vigorous, early and high yielding clone that is sensitive to tapping panel dryness and moderately resistant to wind damage (Chapuset, 2001). This clone requires a moderate stimulation system.

PB 280 is a clone originating from Malaysia that is a cross between PBIG and a Seedling. It was planted for the first time in a Large-Scale Trial (LST) in Côte d'Ivoire in 1989. It is a very vigorous clone with a slightly tilting trunk and an abundant and heavy oblique branching. Significant bending was observed 9 years after planting at SCASO, formerly HEVEGO, in southwestern Côte d'Ivoire.

Clone PB 330, originating from Malaysia, is obtained by crossing PB 5/51 and PB 32/36. Planted for the first time in LST in Côte d'Ivoire in 1989, it has characteristics very similar to those of clone PB 255 (rapid or very active-metabolism). This clone has a rapid growth in height with light secondary 
branches spread along the axis. It's sensitive to damage due to wind (Chapuset, 2001).

\section{Methods}

\section{Experimental design and treatments}

The experimental design was in Randomized Complete Blocks of 6 treatments and 4 repetitions. Each elementary plot consisted of 100 trees, that is, a trial surface area of 4.7 ha on average. These trees were selected on the basis of the homogeneity of their girth at $1 \mathrm{~m}$ above ground, their bare yield (without stimulation) and their rate of tapping panel dryness $(0 \%)$.

Five downward half-spiral tapping frequencies were applied to all clones: d2 (tapping every two days), d3 (tapping every three days), $\mathrm{d} 4$ (tapping every four days), $\mathrm{d} 5$ (tapping every five days) and d6 (tapping every six days). The hormonal stimulation system of the yield was established according to tapping frequencies reduction. The ratings used were the international ratings of latex harvesting technologies (Lukman, 1983; Vijayakumar et al., 2009). The latex harvesting technologies practiced are reported in Table 1.

The trees of the experiment were planted at a density of 510 trees per hectare (7 $\mathrm{m} \times 2.8 \mathrm{~m}$ ). Over nine years of experiment, tapping technology applied on trees followed the classic pattern of tapping panel management of hevea in Côte d'Ivoire (Gohet et al., 1991).

\section{Estimated parameters \\ Rubber yield}

Rubber yield was assessed per treatment. The coagulum, removed at the next tapping, was collected, weighed monthly (weight of fresh material, P.F.) and preserved. The transformation coefficient, dry rubber percentage of a given sample of fresh rubber, was used to calculate the dry rubber yield for each pattern. It was calculated from a coagulum sample per treatment. Each sample was weighed, crimped, dried at $80{ }^{\circ} \mathrm{C}$ in an oven for $24 \mathrm{~h}$ and reweighed.

The dry rubber yield was expressed in kilograms per hectare per year ( $\mathrm{kg} / \mathrm{ha} /$ year).

\section{Isodiametric growth of the trunk}

For each treatment, the trunk girth at $1.70 \mathrm{~m}$ was measured on each tree at the beginning of the experiment and at the end of the physiological cycle (January to February), before the beginning of annual defoliation. The average annual increment was expressed in $\mathrm{cm}$ per year ( $\mathrm{cm} /$ year).

Estimation of the physiological parameters of the latex

The most important physiological parameters of the latex, due to their involvement in the mechanisms related to rubber yield, were analyzed once a year, in November. These included the dry rubber content and the sucrose, inorganic phosphorus and thiol group contents of the latex. Some latex collected by needle under the tapping cut (downward tapping), according to the "latex micro diagnostic" method (MDL, Jacob et al., 1988), made it possible to determine the values of the physiological parameters.

\section{Dry rubber content}

The dry rubber content of the latex was determined by weighing $1 \mathrm{ml}$ of fresh product in a $10-\mathrm{ml}$ pill box before and after steaming at $80{ }^{\circ} \mathrm{C}$ for $24 \mathrm{~h}$.

\section{Sucrose, inorganic phosphorus and thiol compounds}

They were determined from the TCA serum obtained after coagulation of the latex in trichloroacetic acid (TCA). These contents, expressed in millimoles per liter of latex $(\mathrm{mmol} / \mathrm{l})$, were determined by the anthrone method developed by Ashwell (1957) for sucrose, by Taussky and Shorr method (1953) for inorganic phosphorus and the method of Boyne and Ellman (1972) for thiol groups. 
All the data dealing with sucrose, inorganic phosphorus and thiols compounds contents were interpreted based on references values as defined by Jacob et al. (1987).

\section{Profitability of latex harvesting technologies}

Profitability of experienced latex harvesting technologies was assessed. Index considered was the Profit Margin (PM) that was estimated and data were compared within harvesting technologies and clones used. PM was obtained by the difference between the Incomes (R) and Production Cost (PC) according to Equation 1.

$P M(F C F A / h a /$ year $=R(F C F A /$ ha $/$ year $)$

- PC(FCFA/ ha/ year $)$

Incomes are products of the quantity of fresh rubber $\left(\mathrm{Q}_{\mathrm{fl}}\right)$ harvested by the Farm Gate Price ( FGP) of the fresh rubber according to Equation 2.

$R(F C F A /$ ha $/$ year $)=Q_{f l}($ Kgha $/$ year $) \times F G P(F C F A / K g)$

Amount of rubber is the annual average value estimated over nine (9) years (from 1994 to 2003) depending on the clones Tested. The average selling price considered was $352 \mathrm{~F} \mathrm{CFA} / \mathrm{kg}$ corresponding to the discounted average value of the price of fresh rubber over the post-devaluation period from 1994 to 2011 (Mahyao et al., 2014).

Production Cost (PC) includes stimulation cost (K) and labor cost (L). Labor cost takes into account stimulation applying cost and that of the tapping labor varying accordingly. Dealing with this last parameter, the number of working days is the annual number of tappings assuming that all the other variables were equal (ceteris paribus).

Stimulating Product was a ready-to-use one with a purchase cost of $3000 \mathrm{~F}$ CFA. Mixing it with 0.5 liter of water gives approximately $1 \mathrm{~kg}$. Considering $1 \mathrm{~g}$ of stimulating product for one tree that corresponds to $400 \mathrm{~g}$ for $1 \mathrm{ha}$, which represents a proportion $\mathrm{k}$ of the purchasing cost of the product for 1 ha. The cost of agricultural labor considered in the study was $1500 \mathrm{FCFA} /$ day/ha for stimulation and 2000 CFA F/day/ha (L) for tapping. The PC was calculated according to Equation 3:

$P Q(F C F A$ ha/ year $)=K(F C F A$ hal year $)+L(F C F A$ hal year $)$ (3)

With:

$K($ FCFA $/$ ha $/$ year $)=$ CostofStim ulating $\operatorname{Pr}$ oduct $\times$

Frequencyo fStimulati on

(4)

$\begin{array}{lrl}\text { L }(\text { FCFA } & / \text { ha } / \text { year })=(\text { LaborCosto fStimulati on } \times \\ \text { Frequencyo } & \text { fStimulati } & \text { on })+(\text { LaborCostf orTapping } \\ \text { Frequencyo } & \text { fTapping })\end{array}$

(5)

With:

CostofStim ulating Pr oduct $(F C F A / h a)=1 g /$

tree $\times 400$ trees / ha $\times k \times 3000$ FCFA

Frequencyo fStimulati on (NumberofSt imulation / year )

$=4,8$ or 10 times / year

LaborCosto fStimulati on $=1500$ FCFA / ha

LaborCostf orTapping $=2000$ FCFA / day / ha

Frequencyo fTapping (NumberofTa pping / year)

$=52,65,78,104$ or 156 days / year

$\mathrm{k}=0,4$

$1 \mathrm{USD}=500 \mathrm{~F} \mathrm{CFA}$

\section{Statistical analysis}

Data on rubber yield, isodiametric trunk growth, latex micro diagnosis and economic profitability were processed using the statistical software STATISTICA 7.5. An analysis of variance was carried out and the level of significance of the differences between the averages was estimated by the NEWMAN-KEULS test for a threshold of $5 \%$. For the comparison of percentages, the test of comparison of averages using the smallest significant difference at the threshold of $5 \%$ was used. 
Table 1: Applied latex harvesting technologies over nine years in large-scale-trial experiment in clones PB 260, PB280 and PB 330 in Côte d'Ivoire.

\begin{tabular}{|c|c|c|c|}
\hline $\mathbf{N}^{\circ}$ & $\begin{array}{l}\text { Latex harvesting } \\
\text { technologies }\end{array}$ & $\begin{array}{l}\text { IS } \\
(\%)\end{array}$ & Description \\
\hline 1 & $\begin{array}{l}\mathrm{S} / 2 \mathrm{~d} 2 \mathrm{6d} / 7 \mathrm{12} \mathrm{m} / 12 \\
\text { nil stimulation }\end{array}$ & 100 & $\begin{array}{l}\text { Downward half-spiral tapping every two days six working days over seven, Sunday being a day off, twelve months over twelve ; } \\
\text { nil stimulation }\end{array}$ \\
\hline 2 & $\begin{array}{l}\text { S/2 d3 6d/7 12m/12 } \\
\text { ET2.5\% Pa1(1) } 4 / y\end{array}$ & 67 & $\begin{array}{l}\text { Downward half-spiral tapping every three days, six working days over seven, twelve months over twelve ; stimulation using } 2.5 \\
\% \text { concentrated Ethephon by application on tapping panel at a rate of } 1 \mathrm{~g} \text { of stimulant over a } 1 \text {-cm large tape; } 4 \text { stimulations were } \\
\text { made per year. }\end{array}$ \\
\hline 3 & $\begin{array}{l}\text { S/2 d4 6d/7 12m/12 } \\
\text { ET2.5\% Pa1(1) } 4 / y\end{array}$ & 50 & $\begin{array}{l}\text { Downward half-spiral tapping every four days, six working days over seven, twelve months over twelve ; stimulation using } 2.5 \% \\
\text { concentrated Ethephon by application on tapping panel at a rate of } 1 \mathrm{~g} \text { of stimulant over a } 1 \text {-cm large tape; } 4 \text { stimulations were } \\
\text { made per year. }\end{array}$ \\
\hline 4 & $\begin{array}{l}\text { S/2 d4 6d/7 12m/12 } \\
\text { ET2.5\% Pa1(1) 8/y }\end{array}$ & 50 & $\begin{array}{l}\text { Downward half-spiral tapping every four days, six working days over seven, twelve months over twelve ; stimulation using } 2.5 \% \\
\text { concentrated Ethephon by application on tapping panel at a rate of } 1 \mathrm{~g} \text { of stimulant over a } 1 \text {-cm large tape; } 8 \text { stimulations were } \\
\text { made per year. }\end{array}$ \\
\hline 5 & $\begin{array}{l}\text { S/2 d5 6d/7 12m/12 } \\
\text { ET2.5\% Pa1(1) 8/y }\end{array}$ & 40 & $\begin{array}{l}\text { Downward half-spiral tapping every five days, six working days over seven, twelve months over twelve ; stimulation using } 2.5 \% \\
\text { concentrated Ethephon by application on tapping panel at a rate of } 1 \mathrm{~g} \text { of stimulant over a } 1 \text {-cm large tape; } 8 \text { stimulations were } \\
\text { made per year. }\end{array}$ \\
\hline 6 & $\begin{array}{l}\text { S/2 d6 6d/7 12m/12 } \\
\text { ET2.5\% Pa1(1) 10/y }\end{array}$ & 33 & $\begin{array}{l}\text { Downward half-spiral tapping every six days, six working days over seven, twelve months over twelve ; stimulation using } 2.5 \% \\
\text { concentrated Ethephon by application on tapping panel at a rate of } 1 \mathrm{~g} \text { of stimulant over a } 1 \text {-cm large tape; } 10 \text { stimulations were } \\
\text { made per year. }\end{array}$ \\
\hline
\end{tabular}




\section{RESULTS}

Rubber yield

The average annual yield of rubber was significantly influenced by the latex harvesting technology in the clones studied. It varied from 2477 to $2972 \mathrm{~kg} / \mathrm{ha} / \mathrm{year}$, from 1908 to $2382 \mathrm{~kg} / \mathrm{ha} / \mathrm{year}$, and from 1886 to $2439 \mathrm{~kg} / \mathrm{ha} /$ year respectively for clones PB 260, PB 280 and PB 330. Tapped trees every two days without hormonal stimulation (d2 $0 / y$ ) showed average rubber yields that were statistically higher compared with those of trees tapped every six days and stimulated 10 times per year (d6 10/y) in all the clones studied (Table 3).

Regardless of latex harvesting technology, clone PB 260 showed an average rubber yield (2770 $\pm 177 \mathrm{~kg} / \mathrm{ha} / \mathrm{yr})$ above of that of clone PB $330(2297 \pm 206 \mathrm{~kg} / \mathrm{ha} / \mathrm{y})$ and clone PB $280(2169 \pm 157 \mathrm{~kg} / \mathrm{ha} /$ year $)$. Similarly, the most significant average rubber yield (2597) was obtained with the control treatment (d2 0/y) whatever the clone studied (Table 3).

\section{Radial vegetative growth of rubber trees}

The latex harvesting technology had a significant impact on the annual average girth increment of the trees from clones PB 260 and PB 280. The average annual girth increment of the trees of clone PB 330 was however not influenced by the latex harvesting technology (Table 4).

The annual average increments ranged from 2.79 to $3.35 \mathrm{~cm} /$ year (clone PB 260), from 2.57 to $3.06 \mathrm{~cm} /$ year (clone 280) and from 3.05 to $3.19 \mathrm{~cm} /$ year (clone PB 330).

Low tapping frequencies showed in all clones studied annual average girth increments inferior to those of trees tapped at d2 without any stimulation $(3.20 \mathrm{~cm} /$ year $)$. Annual average increment rate was higher in clone PB $330(3.11 \pm 0.07 \mathrm{~cm} /$ year $)$ followed by clone PB $260(3.07 \pm 0.19 \mathrm{~cm} /$ year $)$ and clone PB $280(2.82 \pm 0.16 \mathrm{~cm} /$ year $)$ regardless of the latex harvesting technology applied (Table 4).

\section{Physiological parameters of rubber trees Clone PB 260}

Averages of dry rubber contents (DRC) in latex of the trees from clone PB 260 were very high and statistically equivalent between them. Average values ranged from 54.48 to $58.05 \%$ depending on latex harvesting technology (Table 5).

Dealing with sucrose content, averages of sucrose (Suc) in the latex of the rubber trees from clone PB 260 were not influenced by latex harvesting technology. However, they were moderate for harvesting technologies 2 , 3 and $4(7$ to $8.56 \mathrm{mmol} / \mathrm{l})$ and high for the control (d2 0/y) and harvesting technology 5 (d5 8/y) and 6 (D6 10/y) which respectively showed values ranging from 10.20 to 10.09 $\mathrm{mmol} / \mathrm{l}$ (Table 4).

Regarding inorganic phosphorus content, averages in the latex of the trees from clone PB 260 were influenced by latex harvesting technologies. So, they varied from $18.77 \mathrm{mmol} / 1$ (intermediate) to $30.51 \mathrm{mmol} / 1$ (very high) (Table 5). Harvesting technologies 5 (d5 8/y) and 6 (d6 10/y) showed very high contents that were statistically significant and higher than others harvesting technologies which showed contents ranging from moderate to high.

Concerning thiols content, averages values in the latex of the trees in clone PB 260 were moderate and statistically equivalent from one harvesting technology to another one. They were globally good and varied from 0.64 to $0.79 \mathrm{mmol} / \mathrm{l}$ (Table 5).

\section{Clone PB 280}

In this clone, averages of dry rubber contents (DRC) in latex of trees in were very 
high, significantly influenced by latex harvesting technologies (Table 6). They ranged from 49.39 to $54.29 \%$. However, low tapping frequencies (d4, d5 and d6) and increased hormonal stimulation expressed high average dry rubber content in comparison to high tapping frequencies (d2, d3). Averages of sucrose content (Suc) in latex of the rubber trees in clone PB 280 varied statistically from 6.98 (moderate) to $10.56 \mathrm{mmol} / \mathrm{l}$ (high) depending on the latex harvesting technology (Table 6). Low tapping frequencies showed sucrose contents statistically equivalent to that of control (d2 $0 / y)$ in exception of treatment $4(\mathrm{~d} 48 / \mathrm{y})$ that showed a higher content $(10.56 \mathrm{mmol} / \mathrm{l})$. The average inorganic phosphorus (Pi) contents of the latex of the trees of clone PB 280 were statistically different and were high to very high $(21.54$ to $30.87 \mathrm{mmol} / \mathrm{l})$ for all treatment (Table 6) the control showed a very high level ( $30.87 \mathrm{mmol} / \mathrm{l})$ significantly superior to that of treatments $2(\mathrm{~d} 34 / \mathrm{y}), 5(\mathrm{~d} 58 / \mathrm{y})$ and $6(\mathrm{~d} 6$ 10/y). Concerning thiol contents (RSH), averages in the latex of the trees from clone PB 280 were statistically identical (Table 6). These contents were, overall, very low and ranged from 0.41 to $0.50 \mathrm{mmol} / \mathrm{l}$ depending on the latex harvesting technology.

\section{Clone PB 330}

Average of dry rubber contents (DRC) in the latex of the trees of clone PB 330, from high to very high, were not influenced by the latex harvesting technology (Table 7). However, they varied from 50.37 to $55.33 \%$. The average sucrose contents (Suc) of the latex of the rubber trees of clone PB 330, statistically equivalent to each other, varied from 9.36 (high) to $15.37 \mathrm{mmol} / \mathrm{l}$ (very high) depending on the latex harvesting technology
(Table 7). Regarding inorganic phosphorus (Pi) contents, average were not affected by the latex harvesting technology (Table 7). The average thiol contents (RSH) of the latex of the threes of clone PB 330 were low to high and statistically identical to each other (Table 7). They ranged from 0.51 to $0.78 \mathrm{mmol} / \mathrm{l}$. Concerning thiol group content of the control trees, average in the latex was one of the highest. Trees with low tapping frequencies showed average contents regardless of the frequency of hormonal stimulation.

\section{Profitability of latex harvesting technologies}

The profitability of the different latex harvesting technologies, relative to the data on fresh rubber yield, evolved according to the clone studied (Table 7).

In clone PB 260, all latex harvesting technologies showed statistically equivalent profit margins with the exception of treatments 3 and 6 , which were the least profitable (1 165422 and 1089257 CFA F/ha/year respectively).

The profit margins generated by clone PB 280 were more significant with treatment 3 (1 $095988 \mathrm{CFA}$ F/ha/y) and control (1 055 $825 \mathrm{FCFA} / \mathrm{ha} /$ year). However, they were statistically equal to those of treatments 2,4 and 5 .

As for clone PB 330, all latex harvesting technologies showed statistically equivalent profit margins with the exception of treatment 6 , which was less profitable (948 $658 \mathrm{CFAF} / \mathrm{ha} / \mathrm{year}$ ). Regardless of the latex harvesting technology, clone PB 260 gave an average profit margin (1 186881 CFAF) higher than those of clones PB 330 (1 045643 CFAF) and PB 280 (1 134626 CFAF). 
Table 2: References values of the most important physiological parameters of the latex.

\begin{tabular}{lcccc}
\hline & DRC \% & Suc (mmol/l) & Pi (mmol/l) & RSH (mmol/l) \\
\hline Very high & $>43$ & $>12$ & $>25$ & $>0.90$ \\
\hline High & 38 to 43 & 9 to 12 & 20 to 25 & 0.80 to 0.90 \\
\hline Medium & 33 to 38 & 6 to 9 & 15 to 20 & 0.60 to 0.80 \\
\hline Low & 29 to 33 & 4 to 6 & 10 to 15 & 0.50 to 0.60 \\
\hline Very low & $\leq 29$ & $\leq 4$ & $\leq 10$ & $\leq 0.50$ \\
\hline (JACOB et al., 1987). & & & &
\end{tabular}

Table 3: Annual average rubber yield of the trees of the clones studied according to latex harvesting technologies.

\begin{tabular}{|c|c|c|c|c|c|c|c|}
\hline \multirow{3}{*}{$\begin{array}{l}\text { Latex harvesting technologies } \\
\text { 1. S/2 d2 nil stimulation (control) }\end{array}$} & \multicolumn{7}{|c|}{ Rubber yield (kg/ha/year) } \\
\hline & \multicolumn{2}{|l|}{ PB 260} & \multicolumn{2}{|l|}{ PB 280} & \multicolumn{2}{|c|}{ PB 330} & \multirow{2}{*}{$\begin{array}{c}\text { Average } \\
2597\end{array}$} \\
\hline & 2972 & $\mathbf{a}$ & 2382 & $\mathbf{a}$ & 2439 & $\mathbf{a}$ & \\
\hline 2. $\mathrm{S} / 2 \mathrm{~d} 36 \mathrm{~d} / 7 \mathrm{ET} 2.5 \% \mathrm{~Pa} 1(1) 4 / \mathrm{y}$ & 2914 & $\mathrm{a}$ & 2165 & $\mathrm{ab}$ & 2350 & $\mathrm{a}$ & 2476 \\
\hline 3. $\mathrm{S} / 2 \mathrm{~d} 4$ 6d/7 ET2.5\% Pa1(1) 4/y & 2682 & $\mathrm{~b}$ & 2260 & $\mathrm{ab}$ & 2373 & $\mathrm{a}$ & 2438 \\
\hline 4. $\mathrm{S} / 2 \mathrm{~d} 46 \mathrm{~d} / 7 \mathrm{ET} 2.5 \% \mathrm{~Pa} 1(1) 8 / \mathrm{y}$ & 2814 & $\mathrm{ab}$ & 2179 & $a b$ & 2423 & $\mathrm{a}$ & 2472 \\
\hline 5. S/2 d5 6d/7 ET2.5\% Pa1(1) 8/y & 2759 & $\mathrm{ab}$ & 2121 & $\mathrm{~b}$ & 2309 & $\mathrm{a}$ & 2396 \\
\hline 6. $\mathrm{S} / 2 \mathrm{~d} 6$ 6d/7 ET2.5\% Pa1(1) 10/y & 2477 & $\mathrm{c}$ & 1908 & $\mathrm{c}$ & 1886 & $\mathrm{~b}$ & 2090 \\
\hline Average & 2770 & & 2169 & & 2297 & & 2412 \\
\hline Standard deviation & \pm 177 & & \pm 157 & & \pm 206 & & 180 \\
\hline
\end{tabular}


Table 4: Annual average girth increment in the trees of the clones PB 260, PB 280 and PB 330 studied according to different latex harvesting technologies applied.

\begin{tabular}{lcccccccc}
\hline \multirow{2}{*}{ Latex harvesting technologies } & \multicolumn{7}{c}{ Average annual increment (cm/year) } \\
\cline { 2 - 8 } & PB 260 & PB 280 & PB 330 & Average \\
\hline 1. S/2 d2 nil stimulation (control) & $\mathbf{3 . 3 5}$ & $\mathbf{a}$ & $\mathbf{3 . 0 6}$ & $\mathbf{a}$ & $\mathbf{3 . 1 9}$ & $\mathbf{a}$ & $\mathbf{3 . 2 0}$ \\
2. S/2 d3 6d/7 ET2.5\% Pa1(1) 4/y & 2.79 & $\mathrm{c}$ & 2.57 & $\mathrm{~b}$ & 3.05 & $\mathrm{a}$ & $\mathbf{2 . 8 0}$ \\
3. S/2 d4 6d/7 ET2.5\% Pa1(1) 4/y & 3.10 & $\mathrm{~b}$ & 2.85 & $\mathrm{ab}$ & 3.05 & $\mathrm{a}$ & $\mathbf{3 . 0 0}$ \\
4. S/2 d4 6d/7 ET2.5\% Pa1(1) 8/y & 2.98 & $\mathrm{~b}$ & 2.83 & $\mathrm{ab}$ & 3.07 & $\mathrm{a}$ & $\mathbf{2 . 9 6}$ \\
5. S/2 d5 6d/7 ET2.5\% Pa1(1) 8/y & 3.03 & $\mathrm{~b}$ & 2.77 & $\mathrm{ab}$ & 3.11 & $\mathrm{a}$ & $\mathbf{2 . 9 7}$ \\
6. S/2 d6 6d/7 ET2.5\% Pa1(1) 10/y & 3.16 & $\mathrm{~b}$ & 2.83 & $\mathrm{ab}$ & 3.19 & $\mathrm{a}$ & $\mathbf{3 . 0 6}$ \\
Average & $\mathbf{3 . 0 7}$ & & $\mathbf{2 . 8 2}$ & & $\mathbf{3 . 1 1}$ & & $\mathbf{3 . 0 0}$ \\
Standard deviation & $\pm \mathbf{0 . 1 9}$ & $\mathbf{0 . 1 6}$ & $\pm \mathbf{0 . 0 7}$ & $\mathbf{0 . 1 4}$ \\
\hline
\end{tabular}

In the same column, the averages followed by the same letter are not significantly different (Newmann-Keuls Test at $5 \%$ ).

Table 5: Average values of the physiological parameters of the latex of the trees of clone PB 260 subjected to different latex harvesting technologies.

\begin{tabular}{|c|c|c|c|c|c|c|c|c|}
\hline Latex harvesting technologies & DRC \% & & Suc (mmol & & Pi (mmol & & RSH (mmol & \\
\hline 1. $\mathrm{S} / 2 \mathrm{~d} 2$ nil stimulation (control) & 54.48 & $\mathbf{a}$ & 10.2 & $\mathbf{a}$ & 18.77 & $\mathbf{b}$ & 0.71 & $\mathbf{a}$ \\
\hline 2. $\mathrm{S} / 2 \mathrm{~d} 36 \mathrm{~d} / 7 \mathrm{ET} 2.5 \% \mathrm{~Pa} 1(1) 4 / \mathrm{y}$ & 54.78 & a & 8.56 & $\mathrm{a}$ & 20.89 & $\mathrm{~b}$ & 0.74 & $\mathrm{a}$ \\
\hline 3. $\mathrm{S} / 2 \mathrm{~d} 46 \mathrm{~d} / 7 \mathrm{ET} 2.5 \% \mathrm{~Pa} 1(1) 4 / \mathrm{y}$ & 57.19 & $\mathrm{a}$ & 8.44 & $\mathrm{a}$ & 21.55 & $\mathrm{~b}$ & 0.74 & $\mathrm{a}$ \\
\hline 4. $\mathrm{S} / 2 \mathrm{~d} 4$ 6d/7 ET2.5\% Pa1(1) 8/y & 56.29 & a & 7.00 & $\mathrm{a}$ & 20.19 & $\mathrm{~b}$ & 0.64 & $\mathrm{a}$ \\
\hline 5. $\mathrm{S} / 2 \mathrm{~d} 5$ 6d/7 ET2.5\% Pa1(1) 8/y & 58.05 & $\mathrm{a}$ & 10.2 & $\mathrm{a}$ & 26.96 & $\mathrm{a}$ & 0.79 & $\mathrm{a}$ \\
\hline 6. S/2 d6 6d/7 ET2.5\% Pa1(1) 10/y & 55.82 & a & 10.09 & $\mathrm{a}$ & 30.51 & $\mathrm{a}$ & 0.77 & $\mathrm{a}$ \\
\hline Average & 56.10 & & 9.08 & & 23.15 & & 0.73 & \\
\hline Standard deviation & \pm 1.38 & & \pm 1.31 & & \pm 4.57 & & 2.42 & \\
\hline
\end{tabular}


Table 6: Average values of the physiological parameters of the latex of the trees of clone PB 280 subjected to different latex harvesting technologies.

\begin{tabular}{lcccccccc}
\hline Latex harvesting technologies & DRC \% & Suc (mmol/l) & Pi (mmol/l) & RSH (mmol/l) \\
\hline 1. S/2 d2 nil stimulation (control) & $\mathbf{5 0 . 6 1}$ & bc & $\mathbf{8 . 0 6}$ & b & $\mathbf{3 0 . 8 7}$ & a & $\mathbf{0 . 4 1}$ & a \\
2. S/2 d3 6d/7 ET2.5\% Pa1(1) 4/y & 49.39 & c & 6.98 & b & 23.05 & b & 0.50 & a \\
3. S/2 d4 6d/7 ET2.5\% Pa1(1) 4/y & 53.15 & ab & 9.08 & ab & 24.16 & ab & 0.45 & a \\
4. S/2 d4 6d/7 ET2.5\% Pa1(1) 8/y & 51.26 & abc & 10.56 & a & 27.01 & ab & 0.48 & a \\
5. S/2 d5 6d/7 ET2.5\% Pa1(1) 8/y & 54.29 & a & 7.50 & b & 22.22 & b & 0.47 & a \\
6. S/2 d6 6d/7 ET2.5\% Pa1(1) 10/y & 54.04 & a & 8.35 & b & 21.54 & b & 0.48 & a \\
Average & $\mathbf{5 2 . 1 2}$ & & $\mathbf{8 . 4 2}$ & $\mathbf{2 4 . 8 1}$ & & $\mathbf{0 . 4 7}$ & \\
Standard deviation & \pm 2.00 & \pm 1.27 & \pm 3.54 & $\mathbf{2 . 2 7}$ & \\
\hline In the same column, the averages followed by the same letter are not significantly different (Newmann-Keuls Test at 5\%).
\end{tabular}

Table 7: Average values of the physiological parameters of the latex of the trees of clone PB 330 subjected to different latex harvesting technologies.

\begin{tabular}{|c|c|c|c|c|c|c|c|c|}
\hline \multirow{2}{*}{$\begin{array}{l}\text { Latex harvesting technologies } \\
\text { 1. S/2 d2 nil stimulation (control) }\end{array}$} & \multicolumn{2}{|c|}{ DRC \% } & \multicolumn{2}{|c|}{ Suc $(\mathbf{m m o l} / \mathbf{l})$} & \multicolumn{2}{|c|}{$\begin{array}{c}\mathbf{P i} \\
(\mathrm{mmol} / \mathrm{l})\end{array}$} & \multicolumn{2}{|c|}{ RSH (mmol/l) } \\
\hline & $\mathbf{5 0 . 8 0}$ & $\mathbf{a}$ & 10.02 & $\mathbf{a}$ & 22.98 & $\mathbf{a}$ & 0.78 & $\mathbf{a}$ \\
\hline 2. $\mathrm{S} / 2 \mathrm{~d} 36 \mathrm{~d} / 7 \mathrm{ET} 2.5 \% \mathrm{~Pa} 1(1) 4 / \mathrm{y}$ & 54.15 & $\mathrm{a}$ & 9.36 & $\mathrm{a}$ & 22.99 & $\mathrm{a}$ & 0.60 & $\mathrm{a}$ \\
\hline 3. $\mathrm{S} / 2 \mathrm{~d} 46 \mathrm{~d} / 7 \mathrm{ET} 2.5 \% \mathrm{~Pa} 1(1) 4 / \mathrm{y}$ & 51.06 & $\mathrm{a}$ & 13.39 & $\mathrm{a}$ & 17.92 & $\mathrm{a}$ & 0.54 & $\mathrm{a}$ \\
\hline 4. S/2 d4 6d/7 ET2.5\% Pa1(1) 8/y & 50.37 & $\mathrm{a}$ & 13.58 & $\mathrm{a}$ & 22.52 & $\mathrm{a}$ & 0.51 & $\mathrm{a}$ \\
\hline 5. S/2 d5 6d/7 ET2.5\% Pa1(1) 8/y & 55.33 & $\mathrm{a}$ & 12.30 & $\mathrm{a}$ & 21.13 & $\mathrm{a}$ & 0.57 & $\mathrm{a}$ \\
\hline 6. S/2 d6 6d/7 ET2.5\% Pa1(1) 10/y & 54.95 & $\mathrm{a}$ & 15.37 & $\mathrm{a}$ & 19.58 & $\mathrm{a}$ & 0.55 & $\mathrm{a}$ \\
\hline Average & 52.78 & & 12.34 & & 21.19 & & 0.59 & \\
\hline Standard deviation & \pm 2.27 & & \pm 2.28 & & \pm 2.07 & & 2.21 & \\
\hline
\end{tabular}


Table 8: Profit margins (CFAF/ha/year) depending on latex harvesting technologies applied to the clones studied.

\begin{tabular}{|c|c|c|c|c|c|c|}
\hline \multirow{2}{*}{ Latex harvesting technologies } & \multicolumn{5}{|c|}{ Profit margin (CFAF/ha/year) } & \\
\hline & PB 260 & & PB 280 & & PB 330 & \\
\hline 1. $\mathrm{S} / 2 \mathrm{~d} 2$ nil stimulation (témoin) & 1198843 & a & 1055825 & a & 1128853 & $\mathrm{a}$ \\
\hline 2. $\mathrm{S} / 2 \mathrm{~d} 36 \mathrm{~d} / 7 \mathrm{ET} 2.5 \% \mathrm{~Pa} 1(1) 4 / \mathrm{y}$ & 1238113 & a & 1005749 & $\mathrm{ab}$ & 1146115 & a \\
\hline 3. S/2 d4 6d/7 ET2.5\% Pa1(1) 4/y & 1165422 & $\mathrm{ab}$ & 1095988 & $\mathrm{a}$ & 1197915 & a \\
\hline 4. S/2 d4 6d/7 ET2.5\% Pa1(1) 8/y & 1218474 & $\mathrm{a}$ & 1041146 & $\mathrm{ab}$ & 1215204 & a \\
\hline 5. S/2 d5 6d/7 ET2.5\% Pa1(1) 8/y & 1211176 & $\mathrm{a}$ & 1029506 & $\mathrm{ab}$ & 1171008 & $\mathrm{a}$ \\
\hline 6. S/2 d6 6d/7 ET2.5\% Pa1(1) 10/y & 1089257 & $\mathrm{~b}$ & 928374 & $\mathrm{~b}$ & 948658 & $\mathrm{~b}$ \\
\hline Average & 1186881 & & 1045643 & & 1134626 & \\
\hline Standard deviation & \pm 53566 & & \pm 33579 & & \pm 96510 & \\
\hline
\end{tabular}

\section{DISCUSSION}

Incidence of latex harvesting technologies on rubber yield and radial vegetative growth of rapid-metabolism clones in rubber trees (Hevea brasiliensis)

The assessment of the incidence of the different latex harvesting technologies of active-metabolism clones of rubber tree (Hevea brasiliensis) took into account the rubber yield, the radial vegetative growth, and the physiological profile of the latex of the trees of clones PB 260, PB 280 and PB 330.

Rubber yield in $\mathrm{kg} / \mathrm{ha} /$ year of different clones studied was globaly more significant with tapping intensification. Latex harvesting system using high tapping intensity and no stimulation (d2 0/y) appeared more efficient than those with low tapping intensity in all clones studied. Results obtained confirm those of Jacob et al. (1995) who concluded that in all clones, most frequent tapping induces a more intensive metabolic activity to compensate the loss of significant rubber yield. Indeed, latex-producing function of trees is exalted by tapping (Obouayeba et Boa, 1993; Soumahin, 2010; Atsin et al., 2014) because more rubber tree is tapped, higher its yield is. Such response appears more important in active-metabolism clones characterized by an easy flow in absence of hormonal stimulation. This easy flow of the latex is probably due to a sufficient (nonlimiting) availability of intrinsic (initial) metabolic energy of latex vessels as highlighted by Lacote et al. (2010).

Moreover, at the opposite of findings of Coulibaly (2012) in clone PB 235 and those of Traoré (2015) in clones PB 235 and PB 260 advocating a minimum of hormonal stimulation to optimize yield level, our results show that high tapping intensity (d2) alone is sufficient obtaining a better rubber yield in all 
the clones studied. These results confirm not only those of Obouayeba et al. (1996) and Lacrotte (1991) on the stimulating power of tapping through generation of ethylene in rubber tree tissues, but emphasize the fact observed results could be extend to several clones in rapid metabolic activity class for the expression of their productivity without hormonal stimulation.

Dealing with radial vegetative growth in rubber trees, trees tapped in $\mathrm{d} 2$ and nonstimulated showed an annual average increment more significant than those in trees tapped at reduced frequencies irrespective of the level of hormonal stimulation. This result reflects a low incidence of high tapping frequencies on isodiametric growth of tree trunks in relation to different levels of hormonal stimulation. Although tapping frequency is reduced, increasing hormonal stimulation frequency has a negative effect on the radial vegetative growth of rubber trees (Soumahin, 2010; Diarrassouba, 2013). Furthermore, several studies (Gohet, 1996; Obouayeba, 2005) have reported that competition between production of primary biomass (vegetative growth) and secondary biomass (rubber) is unfavorable to vegetative growth. Indeed, the reconstitution of the latex exported by tapping requires not only energy but also and especially photosynthetic assimilates. However, the results obtained showed that non-stimulated control treatment (d2 0/y) indicated a better rubber yield and vegetative growth in all clones studied. This shows that the reduction in the radial vegetative growth of rubber trees is more probably related to stimulation than tapping.

Effect of latex harvesting technologies on physiological profile of in rapid-metabolism clones of rubber trees (Hevea brasiliensis)

Average dry rubber content assessment of latex revealed very high values in all latex harvesting technologies, whatever the clone. Furthermore, average sucrose content showed by control trees tapped every two days (d2) without any stimulation appeared comparable to that of trees with reduced stimulation and tapping frequencies. Such observation indicates an increased and efficient use of sugar during isoprene metabolism in stimulated trees as well as trees without hormonal stimulation. Indeed, the lower average sucrose content is, the greater its use is and the more efficient and productive the latex-producing function is (Gohet, 1996). These high dry rubber contents therefore reflect the high metabolic regeneration activity which characterizes clones of rapid metabolic activity class. For the same clones, this activity is also more important in reduced tapping frequencies with stimulation than in high tapping frequency without hormonal stimulation (d2 0/y). In line of such results, Compagnon (1986) and Lacrotte (1991) have shown that latex stock reconstitution time frame taken by previous tapping requires a time limit. This means that the longer this period is, the greater the more significant the reconstitution is and the higher the dry rubber content is. The results obtained show that tapping in $\mathrm{d} 2$ without hormonal stimulation therefore has no negative incidence on the dry rubber content. Thus, they indicate that tapping in $\mathrm{d} 2$ was not also a limiting factor for the activation and the regeneration of the latex of the clones studied.

Moderate to high levels of sucrose content observed in latex of clones studied indicates a good supply of latex vessels in relation to rubber trees productivity (Van De Sype, 1984). Indeed, this content reflects latex-producing metabolism activation because sucrose is the raw material and the provider of metabolic energy in isoprene biosynthesis (Jacob et al., 1998; Obouayeba et al., 2006).

High to very high values registered dealing with inorganic phosphorus average contents in latex of clones studied regardless latex harvesting technologies were, however, consistent with the Pi contents of the latex in active-metabolism clones (Gohet et al., 1996; 
Coulibaly, 2012). For each of the clones studied, inorganic phosphorus average contents in latex were globally similar regardless stimulation frequencies applied. This result highlights the activating effect of tapping metabolism as shown by the works of Obouayeba et al. (1996), Dick et al. (2014) and Atsin et al. (2016); high tapping frequency (d2) resulting in a high Pi content in absence of hormonal stimulation. This result confirms that in active-metabolism clones, intrinsic metabolic energy is available and sufficient (Lacote et al., 2010). That is their main characteristic.

For thiol group average contents in latex, trees tapped at low-frequency with different levels of hormonal stimulation showed statistically equivalent values to those of trees tapped every two days (d2) and nonstimulated irrespective of the clone. High tapping frequency does not therefore have a negative effect on thiol group content, but rather results in high concentrations linked to a higher metabolic activity (Jacob et al., 1995). This result shows and confirms that tapping increases the metabolic energy of the tree.

Incidence of latex harvesting technologies on the profitability in clones studied

The economic analysis revealed that the control $(\mathrm{d} 20 / \mathrm{y})$ which showed a rubber yield superior or equal to that of other latex harvesting technologies in the clones studied, generates a lower profit margin although statistically similar to those of low tapping intensities. This is closely related to the level of rubber yield and especially to expenses, mainly those relating to the tapping labor, which has strongly influenced the revenue generated. Indeed, Mahyao et al. (2014) showed that the greater the number of tapping is, the more the operating costs are. And since the number of tapping increases from 78 tapping (d4) to 104 tapping (d3) and to 156 tapping (d2), it is understood that the profit margin of $\mathrm{d} 2$ is lower than those of the other tapping frequencies. These results confirm those of Johari et al. (1998) who reported that a more intensive tapping is not more profitable than a reduced tapping frequency.

\section{Conclusion}

At the end of this study, it appears that clones in rapid metabolic activity class showed a higher rubber yield with tapping intensification. Indeed, high intensity and nonstimulated latex harvesting system (d2 0/y) showed a level of rubber yield comparable to those of the tapping frequencies $\mathrm{d} 3$ and $\mathrm{d} 4 \mathrm{in}$ all the clones studied whatever the level of hormonal stimulation applied. Clones of this metabolic activity class are, therefore, more suitable to tapping than to hormonal stimulation intensification.

These results also revealed that trees tapped in $\mathrm{d} 2$ and non-stimulated had a greater isodiametric increment of the trunk girth than those of the reduced and stimulated tapping frequencies.

Moreover, absence of hormonal stimulation did not have a negative incidence on the physiological parameters of latex of trees in all the clones studied. On the contrary, these trees showed a good inorganic phosphorus content indicating a good availability of the energy at the origin of the activation of the latex-producing metabolism following tapping intensification.

The trees tapped in $\mathrm{d} 2$ and nonstimulated generated a profit margin statistically identical to those of low tapping frequencies irrespective of the level of hormonal stimulation.

Thus, the latex harvesting technologies d2 $0 / y$ and $d 34 / y$ could be envisioned for sustainable and profitable latex harvesting in clones PB 260, PB 280 and PB 330.

\section{COMPETING INTERESTS}

The authors declare that they have no competing interests. 


\section{AUTHORS' CONTRIBUTIONS}

This work was carried out in collaboration between all authors. Authors GJOA and SO designed the study, wrote the protocol and wrote the first draft of the manuscript. GJOA and EFS reviewed the experimental design and all drafts of the manuscript. THK, AM and KMO managed the analysis of the study. Authors GJOA, EFS and KMO collected the study data. THK and AM performed the statistical and economic analysis. All the authors read and approved the final manuscript.

\section{ACKNOWLEDGEMENTS}

The authors thank the «Société Civile Agricole du Sud-Ouest (SCASO)» which hosted the trials and contributed to the data collection for nine years.

\section{REFERENCES}

Ashwell G. 1957. Colorimetric analysis of sugar. Methods Enzymol., 3: 73 - 105.

Atsin GJO, Soumahin EF, Kouakou TH, Elabo AEA, Okoma kM, Obouayeba S. 2016. Agronomic Potential of Some Rubber Tree Clones (Hevea brasiliensis) of the Fast Metabolic Activity Class in the Absence of Hormonal Stimulation in Southwestern of Côte d'Ivoire. Am. J. Exp. Agri. 13(4): 1-13.

Atsin GJO, Soumahin EF, Kouakou HT, Coulibaly LF, Traoré SM, Allé JY, N'guessan AEB, Kouamé C, Obouayeba S. 2014. Impact of reduced tapping frequency on agronomic, physiological and biochemical aspects of clone PB 260 of Hevea brasiliensis in the Centre West of Cote D'Ivoire. J. Rubb. Res., 17(1): $45-56$.

Boyne AF, Ellman GL. 1972. A methodology for analysis of tissue sulphydryl components. Anal. Biochem., 46: 639 - 653.

Chapuset T, Gnagne M, Legnate H, Koffi E, Clément-Démange A. 2000. Les champs des clones à Grande Echelle en
Côte d'Ivoire, situation en 1999. Rapport Sea $n^{\circ}$ 01/2000-A mars 2000, 40-63.

Chapuset TH. 2001. Description des clones étudiés à grande échelle. Rapport CNRA-HEVEA $\mathrm{n}^{\circ}$ 01/01, $36 \mathrm{p}$.

Chrestin H. 1985. La stimulation à l'éthrel de l'hévéa; jusqu'où ne pas aller trop loin. Caouth. Plast., 647/648: 75 - 78.

Compagnon P. 1986. Le Caoutchouc Naturel, Coste R (ed). G.P. Maisonneuve et Larose : Paris ; 595.

Coulibaly LF. 2012. Techniques de récolte du latex adaptées aux clones de l'hévéa (Hevea brasiliensis Muell. Arg. (Euphorbiaceae)) : cas du PB 235 au sud-est de la Côte d'Ivoire. Thèse de Doctorat, Université de CocodyAbidjan, Côte d'Ivoire, $166 \mathrm{p}$.

Diarrassouba M. 2013. Contribution à la définition de technologies de récolte du latex adaptées aux clones de Hevea brasiliensis Muell. Arg. (Euphorbiaceae) des classes d'activité métabolique active, modérée et lente. Thèse de Doctorat de l'Université Félix Houphouët Boigny- Abidjan (Côte d'Ivoire), $207 \mathrm{p}$.

Dick AE, Traoré MS, Elabo AEA, Soumahin EF, Assi EG-M, Atsin GJO, Allé YJ, N'guessan BEA, Kouamé C, OBOUAYEBA S. 2014. Effets de différentes fréquences annuelles de stimulation éthylénique sur les paramètres agrophysiologiques et de sensibilité à l'encoche sèche de Hevea brasiliensis au sud-est de la Côte d'Ivoire : cas des clones PB 235 et PB 260 de la classe d'activité métabolique rapide. Int. J. Biol. Chem. Sci., 8(3): 956-974.

Gohet E, Lacrotte R, Obouayeba S, Commère J. 1991. Tapping System Recommending in West Africa. Proc. Rubb Growers' Conf. Rubb. Res. Inst. Malaysia: Kuala Lumpur, Malaysia. $10 \mathrm{p}$. 
Gohet E, Prévôt JC, Eschbach JM, Clément A, Jacob JL. 1996. Clone, croissance et stimulation, facteurs de la production de latex. Plant., Rech., Dévelop., 3(1) : 30 38.

Gohet E. 1996. La production de latex par Hevea brasiliensis. Relation avec la croissance. Influence de différents facteurs: origine clonale, stimulation hormonale, réserves hydrocarbonées. Thèse de Doctorat d'Université, Université Montpellier II. Sciences et techniques du Languedoc., France, 343 p.

Jacob JL, Lacrotte R, Serres E, Roussel D. 1987. Les paramètres physiologiques du latex d'Hevea brasiliensis. Le diagnostic latex, ses bases, sa mise au point. IRCA, Document interne, $41 \mathrm{p}$.

Jacob JL, Serres E, Prévôt JC, Lacrotte R, Clément-Vidal A, Eschbach JM, D'auzac J. 1988. Mise au point du diagnostic latex. Agritrop, 12: 97 - 118.

Jacob JL, D’auzac J, Prévôt JC, Sérier JB. 1995. Une usine à caoutchouc naturel : L'Hévéa. La recherche, 276 : 538 - 545.

Jacob JL, Prévôt JC, Lacote R, Gohet E, Clément A, Gallois R, Joet T, PujadeRenaud V, D’auzac J. 1998. Les mécanismes biologiques de la production de caoutchouc par Hevea brasiliensis. Plant., Rech., Dév., 5(1): 517.

Johari H, SIvakumaran S, Mohd AS. 1998. Economics of Low Intensity Tapping Systems. Proceedings of Seminar on Low Intensity Tapping Systems (LITS). 10 August 1998, Training Complex, Sungai Buloh, Selangor Darul Ehsan; 103-118.

Lacote R, Gabla O, Obouayeba S, Eschbach JM, Rivano F, Dian K, Gohet E. 2010. Long-term effect of ethylene stimulation on the yield of rubber trees is linked to latex cell biochemistry. Field Crop. Res., 115: 94-98.
Lacrotte R. 1991. Etude des relations entre la teneur en sucres du latex et la production: approche des mécanismes du chargement en saccharose des laticifères de Hevea brasiliensis Muell. Arg. Thèse de Doctorat d'Université, Université des Sciences et Technologies du Languedoc, Montpellier II, 266 p.

Lukman. 1983. Revised international notation for récolte du latex systems. J. Rubber. Res. Inst. Malaysia, 31: 130 - 140.

Mahyao A, Soumahin EF, Koffi C, Coulibaly LF, N'guessan AEB, Kouamé C, Obouayeba S. 2014. Economic Analysis of Compensating Systems for the Scarcity of Tapping Labour in the Rubber Industry in Côte d'Ivoire. Journal of Rubber Research, 17(1): 34-44.

Obouayeba S. 2005. Contribution à la détermination de la maturité physiologique de l'écorce pour la mise en saignée de Hevea brasiliensis. Muell. Arg.: Normes d'ouverture. Thèse de Doctorat. Agro-physiologie. Université de Cocody, $255 \mathrm{p}$.

Obouayeba S, Boa D. 1993. Fréquence et repos annuel de saignée d'Hevea brasiliensis, clone PB 235, dans le sudest de la Côte d'Ivoire. Cahiers Agricultures, 2(6): 387 - 393.

Obouayeba S, Boa D, Kéli ZJ. 1996. Adéquation entre quantité de pâte stimulante et production de caoutchouc d'Hevea brasiliensis dans le sud-est de la Côte d'Ivoire. Tropicultura, 14(2): 54 58.

Obouayeba S, Gabla O, Soumahin EF, Boko AMC, Doumbia A, Koto B, Gnagne YM. 2006. Relation entre l'intensité d'exploitation et la sensibilité à l'encoche sèche de clones d'Hevea brasiliensis. In Tapping Panel Dryness of Rubber Trees. Rubber Research Institute of India; 45-54.

Obouayeba S, Soumahin EF, Boko AMC, Dea GB, Dian K, Gnagne YM. 2008. 
Improvement of productivity of rubber Trees in Smallholding by the Introduction of Upward Tapping in the South-east of Côte d'Ivoire. Journal of Rubber Research, 11(3): 163-170.

Okoma KM. 2008. Etude de la sensibilité au syndrome de l'encoche sèche chez Hevea brasiliensis Muell. Arg. (Euphorbiaceae). Thèse de Doctorat, Université de Cocody-Abidjan, Côte d'Ivoire, $245 \mathrm{p}$.

Serres E, Lacrotte R, Prévot JC, Clément A, Commère J, Jacob JL. 1994. Metabolic aspects of latex regeneration in situ for three Hevea clones. Rubb. Ind. J., 7: 79 84.

Soumahin EF. 2010. Optimisation des systèmes de récolte du latex en hévéaculture par la réduction des intensités de saignées. Thèse de Doctorat, Université de CocodyAbidjan, Côte d'Ivoire, 189 p.

Taussky HH, Shorr E. 1953. A micro colorimetric method for the determination of inorganic phosphorus. J. Biol. Chem., 202: $675-685$.
Traoré MS. 2015. Effets de différentes fréquences annuelles de stimulation éthylénique sur les paramètres agrophysiologiques des clones d'Hevea brasiliensis, PB 235, PB 260, GT 1 et PB 217 au sud-est de la Côte d'Ivoire. Thèse de Doctorat, Université de Cocody-Abidjan, Côte d'Ivoire, $161 \mathrm{p}$.

Van De Sype H. 1984. The dry cut Syndroms of Hevea Brasiliensis, Evolution, Agronomical and Physiological Aspects. In C. R. Coll. Physiol. Amél. Hévéa., Ed., IRCA-CIRAD: Montpellier, France; $249-271$

Vijayakumar KR, Gohet E, Thomas KU, Xiaodi W, Sumarmadji, Rodrigo L, Thanh DK, Sopchoke P, Karunaichamy K, Said MAM. 2009. Revised International Notation for Latex Production Technology. Intern Rub. Res. Dev. Board; 19 p. 